\title{
KAJIAN AWAL PEMBUATAN PUPUK CAIR ORGANIK DARI EFFLUENT PENGOLAHAN LANJUT LIMBAH CAIR PABRIK KELAPA SAWIT (LCPKS) SKALA PILOT
}

\author{
Fristyana Sosanty Lubis, Irvan*, Dedy Anwar, Basril Amirza Harahap, Bambang Trisakti \\ Departemen Teknik Kimia, Fakultas Teknik, Universitas Sumatera Utara, \\ Jl. Almamater Kampus USU, Medan 20155, Indonesia \\ *Email: i_v_a_n_mz@yahoo.com
}

\begin{abstract}
Abstrak
Penelitian ini bertujuan merancang proses pembuatan pupuk cair organik dari limbah cair pabrik kelapa sawit (LCPKS) skala pilot. Bahan yang digunakan adalah effluent pengolahan lanjut LCPKS menjadi biogas dengan starter berupa campuran molase, ragi dan effective microorganism (EM-4).Variabel yang diamati adalah total solid (TS), volatile solid (VS), total suspended solid (TSS), volatile suspended solid (VSS), dan chemical oxygen demand (COD), selain itu dilakukan juga uji kandungan pupuk terhadap produk yang dihasilkan. Penelitian dimulai dari pembuatan starter kemudian dilanjutkan dengan proses fermentasi. Loading rate dimulai dari HRT 2500 hari dan kinerja bioreaktor diamati pada HRT 100, 90 dan 80 hari. Hasil penelitian diperoleh bahwa COD effluent bioreaktor pada pengolahan menurun dari 8.600 hingga $1.580 \mathrm{mg} / \mathrm{l}$ dan hasil uji kandungan pupuk diperoleh kandungan pupuk cair adalah: Nitrogen $0,14 \%, \mathrm{P}_{2} \mathrm{O}_{5} 0,05 \%, \mathrm{~K}_{2} \mathrm{O}$ $0,07 \%, \mathrm{MgO} 0,01 \%, \mathrm{CaO} 0,001 \mathrm{mg} / \mathrm{l}, \mathrm{C}-$ Organik 0,12\%, dan Ratio C/N 0,86.
\end{abstract}

Kata kunci : pupuk cair organik, pengolahan lanjut, biogas, limbah cair pabrik kelapa sawit

\begin{abstract}
The objective of this study is to design an organic liquid fertilizer manufacturing process from palm oil mill effluent (POME) at pilot scale. Materials used were effluent from further processing of biogas fermentation from POME and starter (mixture of molasses, yeast and effective microorganism). Variables measured were total solid (TS), volatile solid (VS), total suspended solid (TSS), volatile suspended solid (VSS), and chemical oxygen demand (COD), in addition, analysis content of liquid fertilizers was performed. The research consisted of production of starters and fermentation process. Loading rate was started from hydraulic retention time (HRT) 2,500 days and bioreactor performance was observed at HRT 100, 90 and 80 days. The results showed that $C O D$ concentration of bioreactor effluent decreased from 8,600 to 1,580 $\mathrm{mg} / \mathrm{l}$ and from analysis content, liquid fertilizers are composed of nitrogen $0.14 \%, \mathrm{P}_{2} \mathrm{O}_{5} 0.05 \%, \mathrm{~K}_{2} \mathrm{O} 0.07 \%, \mathrm{MgO} 0.01 \%$, $\mathrm{CaO} 0.001 \mathrm{mg} /$, C-Organic 0,12\%, and C/N Ratio 0.86 .
\end{abstract}

Keyword : organic liquid fertilizer, further processing, biogas, palm oil mill effluent

\section{Pendahuluan}

Indonesia adalah produsen minyak kelapa sawit Crude Palm Oil (CPO) terbesar di dunia, dengan luas areal perkebunan kelapa sawit pada 2010 diperkirakan sebesar 7 juta hektar. Besarnya produksi CPO ini juga diikuti dengan besarnya produksi limbah cair pabrik kelapa sawit (LCPKS). Produksi LCPKS diperkirakan \pm 30 juta ton per tahun dan saat ini kebanyakan Pabrik Kelapa Sawit (PKS) masih mengolah LCPKS menggunakan sistem open lagoon sebelum dibuang ke lingkungan, yang selain memerlukan lahan luas, menimbulkan bau, dan juga melepaskan gas rumah kaca [3].

Penggunaan LCPKS dengan mengonversinya menjadi biogas telah diaplikasikan pada beberapa PKS di Malaysia dan Indonesia seperti yang dilakukan oleh Novaviro Sdn Bhd, Malaysia. Irvan dkk., melalui Hibah RUSNAS 2009 dan dilanjutkan dengan kerjasama penelitian USUMetawater.co.ltd tahun 2010 telah berhasil melakukan konversi LCPKS menjadi biogas dengan menggunakan fermentor berukuran 2 liter dengan proses termofilik pada temperatur $55^{\circ} \mathrm{C}$ [4].
Walaupun telah berhasil menkonversi LCPKS menjadi biogas, tetapi nilai COD keluaran digester anaerobik masih tinggi yakni \pm 10.000 $\mathrm{mg} / \mathrm{l}$. Keluaran (effluent) ini masih belum dapat dibuang ke lingkungan karena nilai COD nya masih jauh di atas nilai ambang yaitu $\pm 500 \mathrm{mg} / \mathrm{l}$ [3].

Berdasarkan nilai COD effluent tersebut, untuk menurunkan nilai COD-nya, diperlukan pengolahan lanjut yaitu dengan memanfaatan LCPKS sebagai pupuk organik cair yang mempunyai unsur-unsur hara dengan tujuan memperbaiki struktur fisik tanah, meningkatkan aerasi, peresapan, retensi, dan kelembaban, dan meningkatkan perkembangbiakan dan perkembangan akar tanaman. Sehingga dapat digunakan dalam budi daya pertanian dalam mensubsitusi kebutuhan pupuk anorganik yang semakin mahal, juga dapat menjadikan lingkungan lebih bersih dengan mengurangi tumpukan atau akumulasi limbah pada kolam-kolam konvensional di pabrik kelapa sawit.

Tulisan ini memaparkan tentang hasil perancangan proses pembuatan pupuk cair organik beserta pengamatan nilai TS, VS, TSS, VSS, COD 
dan kandungan pupuk cair organik yang diharapkan dapat mewujudkan proses yang zero waste dan zero emission.

\section{Teori}

Pabrik Kelapa Sawit (PKS) memiliki karakteristik limbah cair yang berbeda-beda tetapi pada umumnya mengandung padatan terlarut dan tersuspensi berupa koloid dan residu minyak dengan nilai Biological Oxygen Demand (BOD) yang tinggi, berwarna kecoklatan, dan bersuhu tinggi, seperti yang disajikan pada Tabel 1.

Tabel 1. Karakteristik LCPKS [2,9]

\begin{tabular}{|l|c|c|}
\hline Parameter & Satuan & Kisaran \\
\hline $\begin{array}{l}\text { Biological oxygen } \\
\text { demand (BOD) }\end{array}$ & $\mathrm{mg} / 1$ & $20.000-30.000$ \\
\hline $\begin{array}{l}\text { Chemical oxygen } \\
\text { demand (COD) }\end{array}$ & $\mathrm{mg} / \mathrm{l}$ & $40.000-60.000$ \\
\hline $\begin{array}{l}\text { Total suspended } \\
\text { solid (TSS) }\end{array}$ & $\mathrm{mg} / \mathrm{l}$ & $15.000-40.000$ \\
\hline Total solid (TS) & $\mathrm{mg} / 1$ & $30.000-70.000$ \\
\hline $\begin{array}{l}\text { Minyak dan } \\
\text { Lemak }\end{array}$ & $\mathrm{mg} / 1$ & $5.000-7.000$ \\
\hline NH3-N & $\mathrm{mg} / 1$ & $30-40$ \\
\hline Total N & $\mathrm{mg} / 1$ & $500-800$ \\
\hline Suhu & ${ }^{\circ} \mathrm{C}$ & $90-140$ \\
\hline $\mathrm{pH}$ & - & $4-5$ \\
\hline
\end{tabular}

Pengolahan Limbah Cair Pabrik Kelapa Sawit (LCPKS) menjadi biogas menggunakan digester anaerobik, sebenarnya sudah banyak dilaporkan, bahkan sudah diaplikasikan pada skala komersial pada beberapa PKS di Indonesia dan Malaysia [3]. Akan tetapi, proses ini hanya mampu mereduksi COD hingga $\pm 80 \%$, sehingga keluaran cair (effluent) digester anaerobik, seperti yang disajikan pada Tabel 2, masih jauh dari nilai parameter baku mutu yang ditetapkan.

Tabel 2. Baku Mutu LCPKS keluaran IPAL [5]

\begin{tabular}{|l|c|c|}
\hline Parameter & Satuan & Baku Mutu \\
\hline $\begin{array}{l}\text { Biological oxygen } \\
\text { demand (BOD) }\end{array}$ & $\mathrm{mg} / \mathrm{l}$ & 250 \\
\hline $\begin{array}{l}\text { Chemical oxygen } \\
\text { demand (COD) }\end{array}$ & $\mathrm{mg} / 1$ & 500 \\
\hline $\begin{array}{l}\text { Total suspended } \\
\text { solid (TSS) }\end{array}$ & $\mathrm{mg} / 1$ & 300 \\
\hline Minyak \& Lemak & $\mathrm{mg} / 1$ & 30 \\
\hline $\mathrm{NH}_{3}-\mathrm{N}$ & $\mathrm{mg} / \mathrm{l}$ & 20 \\
\hline $\mathrm{pH}$ & - & $6-9$ \\
\hline $\begin{array}{l}\text { Debit Limbah } \\
\text { Maksimum }\end{array}$ & $\begin{array}{c}\mathrm{m}^{3} / \mathrm{ton} \\
\mathrm{CPO}\end{array}$ & 6 \\
\hline
\end{tabular}

Effluent hasil pengolahan pembuatan biogas mempunyai unsur-unsur hara yang mampu memperbaiki struktur fisik tanah, meningkatkan aerasi, peresapan, retensi, dan kelembaban, serta meningkatkan pertumbuhan dan perkembangan akar tanaman. Komposisi effluent di estimasi mengandung komposisi yang relatif sama dengan komposisi pada LCPKS. Hal ini disebabkan karena proses pengolahan biogas dengan cara fermentasi tidak menghilangkan unsur hara tersebut.

Tabel 3. Komposisi Keluaran (effluent) Digester Anaerobic [3]

\begin{tabular}{|l|c|c|}
\hline Parameter & Satuan & Nilai \\
\hline Total solid (TS) & $\mathrm{mg} / \mathrm{l}$ & 11,900 \\
\hline Volatile solid (VS) & $\mathrm{mg} / \mathrm{l}$ & 7,500 \\
\hline $\begin{array}{l}\text { Total suspended solid } \\
\text { (TSS) }\end{array}$ & $\mathrm{mg} / \mathrm{l}$ & 2,570 \\
\hline $\begin{array}{l}\text { Volatile suspended solid } \\
\text { (VSS) }\end{array}$ & $\mathrm{mg} / \mathrm{l}$ & 2,200 \\
\hline $\begin{array}{l}\text { Biological oxygen } \\
\text { demand (BOD) }\end{array}$ & $\mathrm{mg} / \mathrm{l}$ & 3,050 \\
\hline $\begin{array}{l}\text { Chemical oxygen } \\
\text { demand (COD) }\end{array}$ & $\mathrm{mg} / \mathrm{l}$ & 8,600 \\
\hline $\mathrm{T}-\mathrm{N}$ & $\mathrm{mg} / \mathrm{l}$ & 490 \\
\hline $\mathrm{NH}{ }_{3}-\mathrm{N}$ & $\mathrm{mg} / \mathrm{l}$ & 65 \\
\hline $\mathrm{T}-\mathrm{P}$ & $\mathrm{mg} / \mathrm{l}$ & 110 \\
\hline $\mathrm{K}$ & $\mathrm{mg} / \mathrm{l}$ & 1,900 \\
\hline $\mathrm{Ca}$ & $\mathrm{mg} / \mathrm{l}$ & 23 \\
\hline $\mathrm{Mg}$ & $\mathrm{mg} / \mathrm{l}$ & 256 \\
\hline $\mathrm{Cd}$ & $\mathrm{mg} / \mathrm{l}$ & $<0.01$ \\
\hline $\mathrm{As}$ & $\mathrm{mg} / \mathrm{l}$ & $<0.01$ \\
\hline $\mathrm{Zn}$ & $\mathrm{mg} / \mathrm{l}$ & 0.61 \\
\hline $\mathrm{Cr}$ & $\mathrm{mg} / \mathrm{l}$ & 0.04 \\
\hline $\mathrm{Hg}$ & $\mathrm{mg} / \mathrm{l}$ & $<0.0005$ \\
\hline
\end{tabular}

Proses pembuatan pupuk organik secara skematik disajikankan pada Gambar 1 pada gambar tersebut terlihat jelas bahwa pembuatan pupuk organik merupakan pengolahan lanjut konversi LCPKS menjadi biogas. Effluent yang digunakan sebagai bahan baku pembuatan pupuk organik aktif sudah melewati proses degradasi anaerob di tangki fermentor pengolahan biogas. Effluent dari fermentor biogas masih mengandung bakteri pendegradasi metana dan pendegradasi karbondioksida, yang ternyata merupakan salah satu bakteri penambat nitrogen [6].

Methanobacterium dan Methanobacillus yang terdapat dalam effluent diketahui dapat membentuk $\mathrm{N}_{2}$ dan untuk menambah unsur makro lain seperti posfat dibutuhkan bakteri pengolahnya yaitu Bacillus.sp, yang belum diketahui kuantitasnya didalam effluent. Oleh karena itu dibutuhkan aktivator yang dapat menambah mikroorganisme didalam pupuk organik aktif. Proses pembuatan pupuk dilakukan menggunakan larutan effective microorganisme 4 disingkat EM-4.

\section{Metodologi Penelitian}

Penelitian ini dilakukan di Laboratorium Pilot Plant Pembangkit Listrik Tenaga Biogas, Pusdiklat LPPM, Universitas Sumatera Utara. Bahan yang digunakan adalah effluent LCPKS yang berasal dari bioreaktor anaerobik pengolahan biogas. Sedangkan peralatan yang digunakan adalah pompa, agitator, bioreaktor, thermocouple, dan coil pendingin. Flowsheet pembuatan pupuk cair organik diperlihatkan pada Gambar 1. 


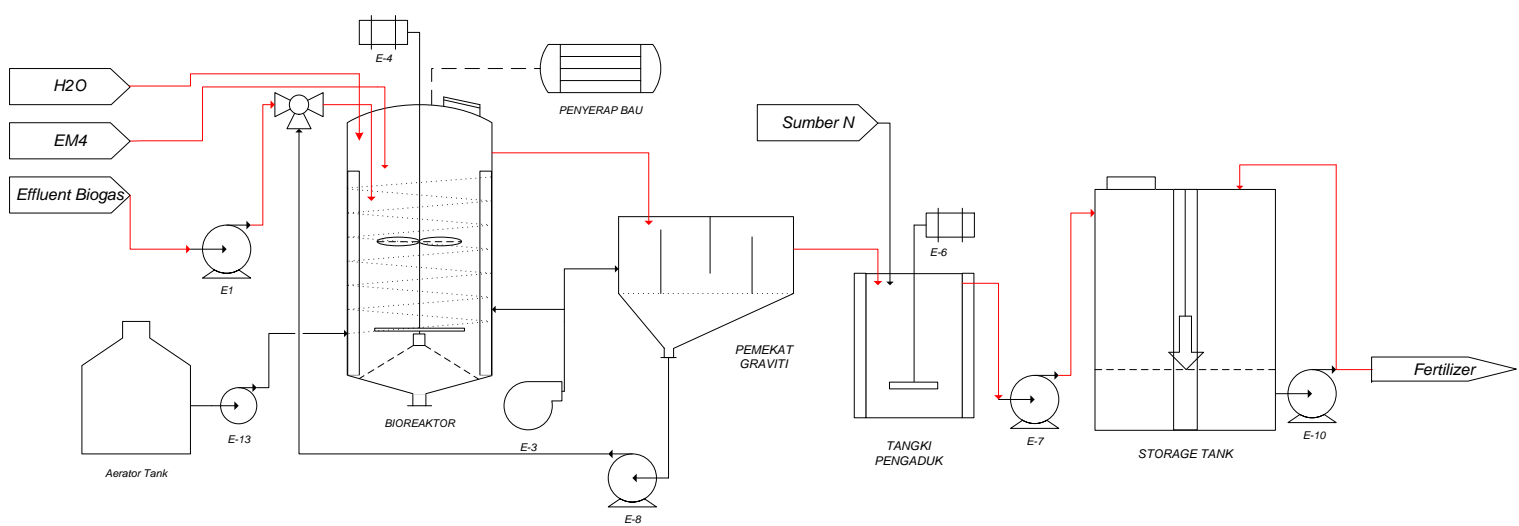

Gambar 1. Flowsheet Pembuatan Pupuk Cair Organik

Peralatan analisis yang digunakan adalah furnace, oven, cawan penguap, neraca analitik, buret, magnetic stirrer, dan desikator.

Tahapan penelitian adalah perancangan dan pabrikasi pilot plant, komisioning (yaitu melakukan test run dari semua peralatan dan sekaligus melakukan kalibrasi terhadap peralatan), melakukan perparasi umpan, loading up, operasi target, sampai pengujian sampel dengan parameter karakterisasi meliputi TS, VS, TSS, VSS, dan COD yang diakhiri dengan uji kandungan pupuk cair organik.

\section{Hasil dan Pembahasan}

1.Perubahan Nilai $\mathrm{pH}$

$\mathrm{pH}$ mempunyai arti yang sangat penting di dalam pengolahan limbah cair karena dari $\mathrm{pH}$ dapat diketahui kondisi mikroorganisme yang ada di dalam limbah cair (effluent). Gambar 2 memperlihatkan hasil pengamatan nilai $\mathrm{pH}$.

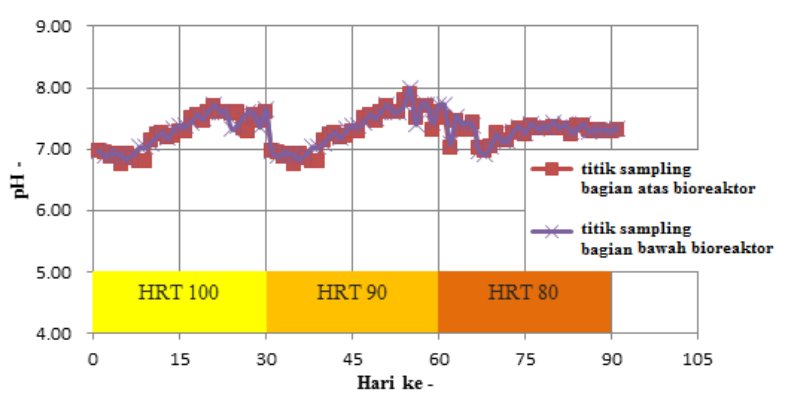

Gambar 2. Perubahan nilai pH

Dari Gambar 2 terlihat grafik pH mengalami peningkatan pada awal proses pengolahan kemudian terjadi penurunan kemudian terjadi kenaikan kembali dan hampir menunjukkan $\mathrm{pH}$ yang stabil pada tahap akhir. Peningkatan nilai $\mathrm{pH}$ pada tiap HRT selama proses pengolahan merupakan akibat perubahan kandungan nitrogen, alkalinitas pada proses nitrifikasi, Pada proses nitrifikasi, nitrogen organik diubah menjadi nitrit yang selanjutnya diubah menjadi nitrat dengan melibatkan mikroorganisme dalam kondisi aerobik, pembentukan nitrat berlangsung pada $\mathrm{pH}$ optimal $7,0-8,3[10]$.

\section{Perubahan Nilai TS dan VS}

Nilai TS dan VS merupakan gambaran nilai kandungan padatan dalam limbah. Adapun hasil pengukuran nilai TS dan VS diperlihatkan pada Gambar 3 dan 4.

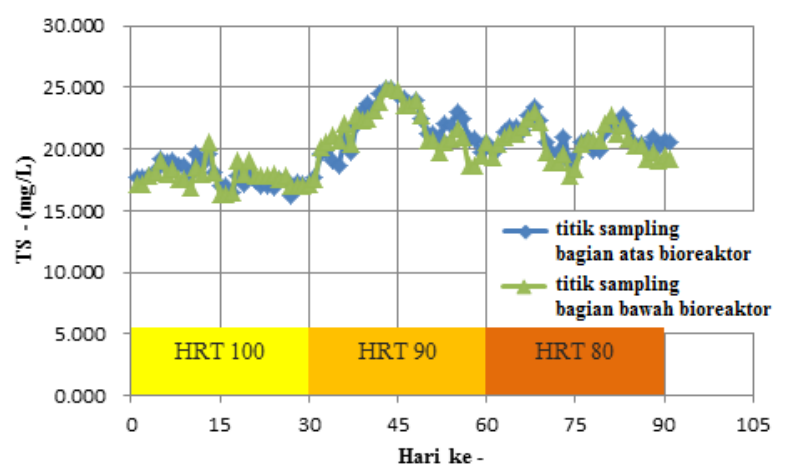

Gambar 3. Perubahan nilai TS

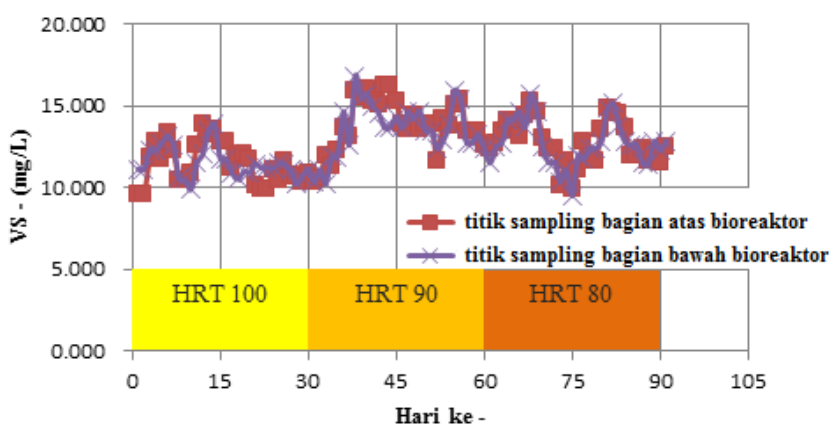

Gambar 4. Perubahan nilai VS

Dari Gambar 3 dan 4 dapat dilihat bahwa nilai TS dan VS yang diperoleh cenderung menurun pada akhir tiap HRT, meskipun tidak terjadi penurunan secara linear. Selain itu dapat dilihat grafik perubahan nilai TS dan VS mendekati kurva pertumbuhan mikroba.

Kadar TS dan VS semakin menurun seiring dengan bertambahnya waktu, hal ini disebabkan bakteri akan mengurai padatan yang terkandung dalam POME, sehingga nilai VS pada tangki akan semakin menurun [1]. 
3. Perubahan Nilai Mixed Liquor Suspended Solid (MLSS)

Penyaringan MLSS dilakukan dengan menyaring padatan tersuspensi yang tidak dapat melalui kertas saring Whatman no. 41 yang memiliki ukuran pori $0,45 \mu \mathrm{m}$. Penyaringan dilakukan dengan mengunakan pompa vakum untuk menyerap air, kemudian kertas saring bersama filtrate dipanaskan pada suhu operasi $120^{\circ} \mathrm{C}$ selama 4 jam. Hasil pengukuran nilai MLSS diperlihatkan pada Gambar 5.

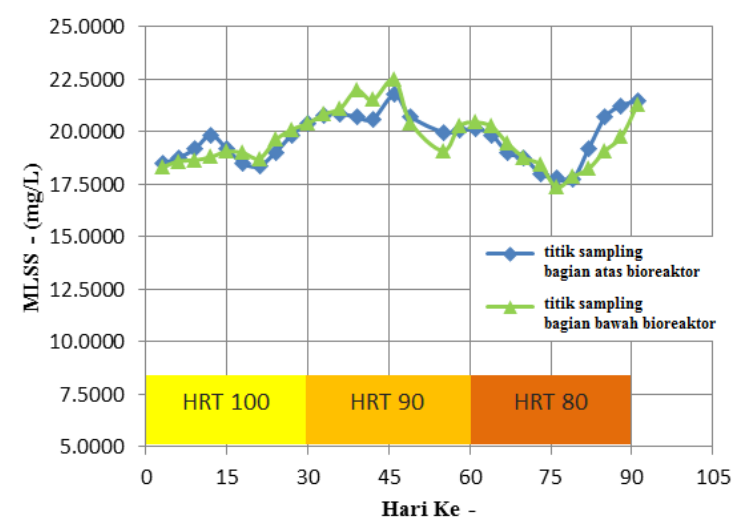

Gambar 5. Perubahan nilai MLSS

Dari Gambar 5 terlihat MLSS meningkat dengan bertambahnya waktu pengolahan, namun pada pertengahan dari tiap HRT, MLSS mengalami penurunan hal ini sesuai dengan fase pertumbuhan mikroba dimana dari awal penambahan umpan terjadi adaptasi sampai pada pertengahan HRT mikroba berada pada fasa stasioner dan kemudian perlahan mengalami penurunan.

Pada HRT 100 hari dan HRT 90 hari grafik menunjukkan fase yang sesuai dengan kurva pertumbuhan mikroba, namun pada HRT 80 hari terjadi penyimpangan dimana pada pertengahan HRT 80 hari yang seharusnya mengalami kenaikan terjadi penurunan. Jika didasarkan pada nilai TS dan nilai VS pada HRT 80 hari nilainya mengalami penurunan. Hal ini disebabkan oleh bahwa keadaan umpan yang berbeda sehingga mempengaruhi aktivitas mikroba. Perbedaan karakteristik umpan terjadi karena kondisi LCPKS yang diambil dari PKS juga tidak stabil (sesuai dengan kondisi buah kelapa sawit dan pengolahan di PKS setiap hari).

\section{Perubahan Nilai Mixed Liquor Volatile Suspended Solid (MLVSS)}

Perkembangan bakteri ditandai dengan perubahan warna suspensi dari hitam menjadi hitam pekat dan terjadi peningkatan MLSS dan MLVSS. Sehingga dapat dikatakan MLVSS merupakan komponen biomassa untuk menyatakan konsentrasi mikroorganisme secara tidak langsung [7]. Hasil pengkuran terhadap nilai MLVSS dipelihatkan pada Gambar 6.

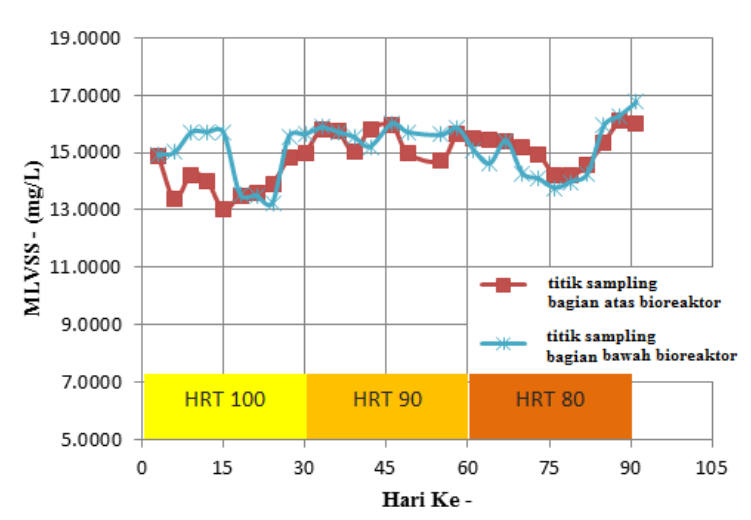

Gambar 6. Perubahan nilai MLVSS

Dari Gambar 6 terlihat bahwa terjadi peningkatan nilai MLVSS yang merupakan suatu pendekatan untuk menyatakan jumlah populasi bakteri. Peningkatan nilai MLVSS tersebut menunjukkan bahwa bakteri berada pada fase pertumbuhan dengan bahan organik dalam limbah sebagai makanannya. Meskipun pada beberapa titik mengalami penurunan karena kondisi LCPKS yang tidak stabil saat diambil dari PKS Adolina.

\section{Perubahan Nilai Chemical Oxygen Demand (COD)}

Nilai COD menunjukkan jumlah kebutuhan oksigen yang ekivalen dengan kandungan bahan organik pada air limbah (effluent) yang dapat dioksidasi oleh oksidan kimia yang kuat. Oksidasi bahan organik menghasilkan $\mathrm{CO}_{2}$ dan $\mathrm{H}_{2} \mathrm{O}$. Nilai COD akan semakin menurun akibat proses oksidasi dan sebagian bahan organik dikonversi menjadi sel baru [8]. Grafik perubahan nilai COD ditunjukkan pada Gambar 7.

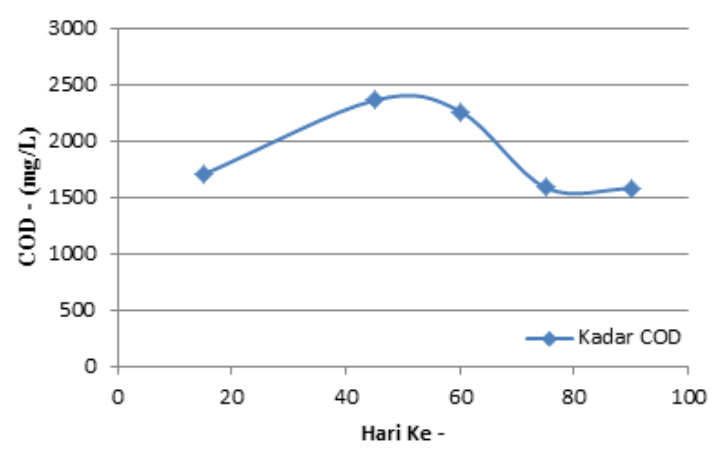

Gambar 7. Perubahan nilai COD

Gambar 7 menunjukkan perubahan kadar COD pada limbah cair (effluent). Dari Gambar 7 dapat dilihat kondisi COD diukur pada hari ke-15 pengolahan. Laju degradasi COD awal $1.705 \mathrm{mg} / \mathrm{l}$ dan mengalami kenaikan pada HRT operasional yang lebih stabil sehingga terjadi kenaikan menjadi $2.362 \mathrm{mg} / \mathrm{l}$ dan setelah proses pengolahan berjalan selama 90 hari kadar COD menjadi $1.580 \mathrm{mg} / \mathrm{l}$. Perubahan nilai COD terlihat jelas menunjukkan mikroorganisme dapat mendegradasi limbah cair (effluent) menggunakan proses aerobik dengan konsentrasi biomassa (MLVSS) yang tinggi. 


\section{Uji Kandungan Pupuk}

Pada tahap terakhir penelitian yaitu pada pada HRT 80 hari, dilakukan pengujian kandungan pupuk organik yang diproduksi untuk mengukur kandungan unsur hara yang terdapat didalam pupuk cair yang dihasilkan. Tabel 4 menunjukkan hasil uji kandungan pupuk yang diperoleh.

Tabel 4. Hasil Uji Kandungan Pupuk

\begin{tabular}{|l|c|c|c|}
\hline Parameter & Satuan & $\begin{array}{c}\text { Hasil } \\
\text { Uji }\end{array}$ & Metode Uji \\
\hline Nitrogen & $\%$ & 0.14 & SNI 2803.2010 \\
\hline $\mathrm{P}_{2} \mathrm{O}_{5}$ & $\%$ & 0.05 & SNI 2803.2010 \\
\hline $\mathrm{K}_{2} \mathrm{O}$ & $\%$ & 0.07 & SNI 2803.2010 \\
\hline $\mathrm{MgO}$ & $\%$ & 0.01 & AAS \\
\hline $\mathrm{CaO}$ & $\mathrm{mg} / \mathrm{L}$ & $\leq 0.001$ & AAS \\
\hline $\mathrm{C}$ - Organik & $\%$ & 0.12 & Walkey \& Black \\
\hline $\mathrm{pH}$ & - & 8.09 & Potensiometri \\
\hline $\mathrm{Ratio}$ C/N & - & 0.86 & - \\
\hline
\end{tabular}

Dari Tabel 4. dapat dilihat bahwa pupuk yang diperoleh mengandung 6 unsur makro yang dibutuhkan oleh tanaman, namun dari analisa $\mathrm{C} / \mathrm{N}$ rasio menyimpang dari kriteria pupuk cair organik pada umumnya. Hal ini disebabkan rendahnya kadar C-Organik dan tingginya Nitrogen yang dikandung pupuk yang disebabkan tingginya degradasi nitrogen oleh bakteri pada bioreaktor.

\section{Ujicoba Pemakaian Pupuk Cair Organik}

Ujicoba pupuk cair organik dilakukan terhadap tanaman jagung dimulai dari penyiapan media, penanaman, pemeliharaan dan pemupukan, pemanenan, pengambilan data tanaman. Pada Gambar 8 menampilkan proses pemupukan dengan pupuk cair organik.

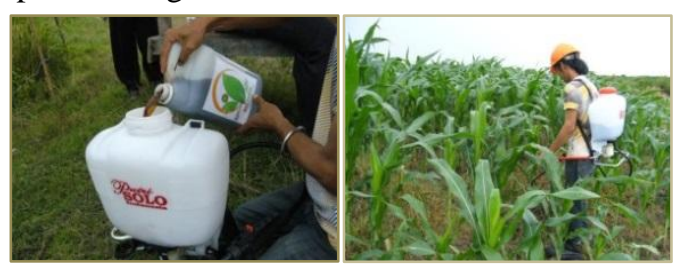

Gambar 8. Proses Pemupukan

Setelah dilakukan pemupukan maka dilakukan pengambilan data. Pengambilan data tanaman jagung diambil secara acak, walaupun demikian pada kenyataannya bila dilihat secara visual, baik tanaman maupun buah jagungnya terlihat memiliki ukuran yang seragam.

Data rata-rata yang diperoleh untuk tanaman yang gunakan sebagai uji pemakaian pupuk terlihat pada Tabel 5.

Tabel 5. Data Tanaman Umur 2,5 bulan

\begin{tabular}{|c|l|c|c|}
\hline No. & Bagian & $\begin{array}{c}\text { Tinggi/Panjang } \\
(\mathbf{c m})\end{array}$ & $\begin{array}{c}\text { Diameter/lebar } \\
(\mathbf{c m})\end{array}$ \\
\hline 1 & Batang & 200 & 3,0 \\
\hline 2 & Daun & 100 & 10,0 \\
\hline
\end{tabular}

Data rata-rata untuk pengukuran buah dari tanaman yang digunakan sebagai uji pemakaian pupuk terlihat pada Tabel 6 .

Tabel 6. Data Buah Umur 2,5 bulan

\begin{tabular}{|c|c|c|c|}
\hline No. & $\begin{array}{c}\text { Buah } \\
\text { Jagung }\end{array}$ & $\begin{array}{c}\text { Tinggi/Panjang } \\
(\mathbf{c m})\end{array}$ & $\begin{array}{c}\text { Diameter/lebar } \\
(\mathbf{c m})\end{array}$ \\
\hline 1 & Sampel 1 & 30 & 4,5 \\
\hline 2 & Sampel 2 & 25 & 4,0 \\
\hline 3 & Sampel 3 & 20 & 6,5 \\
\hline
\end{tabular}

Dapat dilihat dari Tabel 6 yaitu buah tua/kering memiliki ukuran buah yang cukup panjang dan diameter yang cukup besar seperti buah jagung dengan pemakaian pupuk komersial pada umumnya, hal ini menunjukkan penggunaan pupuk yang cukup mempengaruhi tanaman jagung.

\section{Kesimpulan}

1. Perubahan nilai $\mathrm{pH}$ selama proses pengolahan berada pada rentang 6,7 - 8,0 mengalami peningkatan dari awal proses pengolahan, nilai pH 6,50. Merupakan akibat perubahan kandungan nitrogen, alkalinitas dan terutama proses nitrifikasi.

2. Pengukuran Nilai TS (Total Solid) dan VS (Volatile Solid) untuk tiap HRT mengalami penurunan pada pertengahan HRT seiring bertambahnya waktu yang menunjukkan bakteri mampu menguraikan padatan yang terkandung dalam effluent.

3. Laju MLSS (Mixed Liquor Suspended Solid) untuk tiap awal HRT mengalami penurunan namun perlahan mengalami kenaikan dengan bertambahnya waktu pengolahan yang menunjukkan laju perombakan kandungan organik di dalam limbah cair (effluent).

4. Pengukuran nilai MLVSS untuk tiap awal HRT mengalami penurunan namun perlahan mengalami kenaikan dengan bertambahnya waktu pengolahan yang menunjukkan komponen biomassa untuk menyatakan konsentrasi mikroorganisme mengalami pertumbuhan.

5. Penurunan kadar COD $2.362 \mathrm{mg} / \mathrm{l}$ menjadi $1.580 \mathrm{mg} / \mathrm{l}$ akibat proses oksidasi dan sebagian bahan organik dikonversi menjadi sel baru bakteri.

6. Produk pembuatan pupuk organik aktif memiliki kandungan unsur hara yang menyerupai pupuk organik dan menunjukkan hasil yang bagus pada percobaan tanaman.

\section{Ucapan Terimakasih}

Penulis mengucapkan terimakasih kepada Direktur Jendral Pendidikan Tinggi Republik Indonesia yang telah mendanai penelitian ini melalui Hibah Kompetitif Penelitian Unggulan Strategis Nasional No. 169/SP2H/PL/ Dit.Litabmas /III/2012 tanggal 7 Maret 2012. Dan juga kepada METAWATER.co.ltd - Jepang. 


\section{Pustaka}

[1] Chan, Yi Jing, et al, An Optimization of palm oil mill effluent treatment in an integrated Anaerobic-Aerobic Bioreactor, Department of Chemical and Environmental Engineering, The University of Nottingham Malaysia Campus, Sustainable Environment Research Vol.23 (3) p.153-170, 2013.

[2] Departemen Pertanian, Pedoman Pengelolaan Limbah Industri Kelapa Sawit, Ditjen PPHP, Jakarta, p. 15-18, 2006.

[3] Irvan, dkk, Pembuatan pupuk organik aktif dari pengolahan lanjut limbah cair pabrik kelapa sawit, Laporan Hasil Penelitian, Universitas Sumatera Utara, Medan, 2011.

[4] Irvan, et al, Methane Emission from Digestion of Palm Oil Mill Effluent (POME) in a Thermophilic Anaerobic Reactor, Chemical Engginering Department, University of Sumatera Utara, International Journal of Science and Engineering, Vol 3 (1), p. 32-35, 2012.

[5] Keputusan Menteri KLH Nomor KEP 51/MEN KLH/10/1995 tentang Baku Mutu Limbah Cair bagi Kegiatan Industri.

[6] Kyuma, K., Paddy Soil Science, Kyoto University Press and Trans Pacific Press, European Journal of Soil Science Volume 56.(2), p. 274, 2005.

[7] Metcalf \& Eddy, Wastewater Engineering Treatment and Reuse, Mc Graw Hill, 2003.

[8] Romli, M, Suprihatin dan Dinna Sulida, Penentuan Nilai Parameter Kinetika Lumpur Aktif untuk Pengolahan Air Lindi Sampah (Leachate), Jur.Tek. Ind. Pert. Vol.14(2), 5526. Fak. Teknologi Pertanian, IPB: Bogor, 2010.

[9] Rupani, P.F., R.P. Singh, M.H. Ibrahim, \& N. Esa. Review of Current Palm Oil Mill Effluent (POME) Treatment Methods Vermicomposting as a Sustainable Practice. World Applied Sciences Journal, Vol 11(1), p. 70-81, 2010.

[10] Sawyer, N.C. dan McCarty, L.P, Chemistry for Environmetal Engineering, McGraw-Hill Kogakusha, Ltd, Tokyo, 1986. 